\title{
Stable isotope and hydrochemistry reveal source and quality of groundwater around Qinghai Lake, NE Qinghai-Tibet Plateau, China
}

\author{
Dongsheng $\mathrm{Li}^{1}$, Buli Cui ${ }^{1}$, Ying Wang ${ }^{1}$, Yaxuan Wang ${ }^{1}$, and Baofu Jiang ${ }^{1}$ \\ ${ }^{1}$ Ludong University
}

May 5, 2020

\begin{abstract}
The integrated use of isotopic and hydrochemical tracers is an effective approach for investigating complex hydrological processes of groundwater. Thorough understanding of recharge and quality of the groundwater is usually a prerequisite for effective groundwater management. This study investigated the water level, stable isotope and hydrochemistry of groundwater around the Qinghai Lake to reveal the recharge sources, hydrochemical evolution and water quality of groundwater. The relative altitudes of groundwater level ranged from -1.27 to $122.91 \mathrm{~m}$ with hydraulic gradient ranging from -6.20 to 43.14the groundwater was flowing into the lake. Most of the groundwater points lay close to the local meteoric water line, and the slope of Local Evaporation Line of groundwater (LEL: $\delta 2 \mathrm{H}=6.08 \delta 18 \mathrm{O}-3.01$ ) was lower than the slopes of the LMWL, indicating that the groundwater were recharged primarily from precipitation at different altitude in the basin, though it had undergone varying degrees of evaporation. The hydrochemical analysis showed that the groundwater was mainly freshwater and its hydrochemical type was Ca-Mg-HCO3. The groundwater chemistry was mainly controlled by carbonate dissolution around Qinghai Lake. Furthermore, high TDS and high concentrations of $\mathrm{Na}+, \mathrm{Mg} 2+, \mathrm{Cl}-$, or $\mathrm{SO} 42-$ in several groundwater were caused by the recharge source of lake water, the recharge source of fissure water, or by the dissolution of evaporite. The main sources of nitrate (NO3-) in groundwater around Qinghai Lake were animal feces and sewage, suggesting that the pollution of groundwater should be paid more attention in animal husbandry areas on the Qinghai-Tibet Plateau, although the industrial and urbanization rates were relative low on the plateau. The scientific planning and engineering management of livestock manure and wastewater discharge in animal husbandry regions are very necessary to be carried out urgently, which could not only protect water resources for drinking, but also contribute to human health and sustainable development of the ecological environment of the Qinghai-Tibet Plateau.
\end{abstract}

\section{Title page}

Stable isotope and hydrochemistry reveal source and quality of groundwater around Qinghai Lake, NE Qinghai-Tibet Plateau, China

Dong-sheng Li, Bu-li Cui*, Ying Wang, Ya-Xuan Wang, Bao-Fu Jiang

School of Resources and Environmental Engineering, Ludong University, Yantai 264025, China

*Corresponding author:

Bu-Li Cui, School of Resources and Environmental Engineering, Ludong University, No. 186 Hongqizhong Street, Yantai, Shandong, 264025, China. Tel: +86-535-18953511817, Email:cuibuli@163.com

Abstract:The integrated use of isotopic and hydrochemical tracers is an effective approach for investigating complex hydrological processes of groundwater. Thorough understanding of recharge and quality of the groundwater is usually a prerequisite for effective groundwater management. This study investigated the 
water level, stable isotope and hydrochemistry of groundwater around the Qinghai Lake to reveal the recharge sources, hydrochemical evolution and water quality of groundwater. The relative altitudes of groundwater level ranged from -1.27 to $122.91 \mathrm{~m}$ (mean $25.70 \mathrm{~m}$ ) with hydraulic gradient ranging from -6.20 to 43.14Lake, indicating most of the groundwater was flowing into the lake. Most of the groundwater points lay close to the local meteoric water line (LMWL: $\delta^{2} \mathrm{H}=7.80 \delta^{18} \mathrm{O}+10.98$ ), and the slope of Local Evaporation Line of groundwater (LEL: $\delta^{2} \mathrm{H}=6.08 \delta^{18} \mathrm{O}-3.01$ ) was lower than the slopes of the LMWL, indicating that the groundwater were recharged primarily from precipitation at different altitude in the basin, though it had undergone varying degrees of evaporation. The hydrochemical analysis showed that the groundwater was mainly freshwater and its hydrochemical type was $\mathrm{Ca}-\mathrm{Mg}-\mathrm{HCO}_{3}$. The groundwater chemistry was mainly controlled by carbonate dissolution around Qinghai Lake. Furthermore, high TDS and high concentrations of $\mathrm{Na}^{+}, \mathrm{Mg}^{2+}, \mathrm{Cl}^{-}$, or $\mathrm{SO}_{4}{ }^{2-}$ in several groundwater were caused by the recharge source of lake water (G29), the recharge source of fissure water (G1 and G6), or by the dissolution of evaporite (G4 and G25). The groundwater in location G4, G6, G11, G16, G24 and G25 were all currently exceed the drinking standards and not suitable for drinking. The main sources of nitrate $\left(\mathrm{NO}_{3}{ }^{-}\right)$in groundwater around Qinghai Lake were animal feces and sewage, suggesting that the pollution of groundwater should be paid more attention in animal husbandry areas on the Qinghai-Tibet Plateau, although the industrial and urbanization rates were relative low on the plateau. The scientific planning and engineering management of livestock manure and wastewater discharge in animal husbandry regions are very necessary to be carried out urgently, which could not only protect water resources for drinking, but also contribute to human health and sustainable development of the ecological environment of the Qinghai-Tibet Plateau.

Key words:Stable isotope; Hydrochemistry; Groundwater; Qinghai Lake; Qinghai-Tibet Plateau.

\section{Introduction}

Groundwater is a strategic and life-sustaining resource that is utilised for drinking water by 1.5 billion people around the world (Alley et al., 2002). Meanwhile, it plays significant roles in agriculture, the health of ecosystems, and the sustainable development of human societies and economies, especially in cold and semi-arid regions where surface water resources are relatively deficient (Giordano et al., 2009; Siebert et al., 2010; Qiu, 2010; Gleeson et al., 2012; Gleeson et al., 2016; Van Loon et al., 2016). In recent years, groundwater quality has been affected by the intensification of human activities as well as global climate change, which has attracted extensive attention worldwide (Li et al., 2013). Previous studies have found that groundwater levels have fallen at a phenomenal rate on both regional and global scales (Postel et al., 1996; Vorosmarty et al., 2000; Oki et al., 2006; Giordano et al., 2009; Rodell et al., 2009; Gleeson et al., 2012; Wada et al., 2012). Unsustainable depletion of groundwater would lead to a series of environmental problems, such as ground subsidence, aquifer unwatering, saltwater intrusion, and serious ecological degeneration (Matter et al., 2006; Edmunds, 2009; Liu et al., 2015; Goldin, 2016). Therefore, comprehensive studies of the spatial distribution, water quality, recharge source and hydrochemical evolution of regional groundwater are the foundation for the rational use of groundwater resources, which are also essential and contribute to the scientific management and sustainable development of regional water resources (Adams et al., 2001; Edmunds et al., 2006; Chang \& Wang, 2010). The integrated use of isotopic and hydrochemical technology is an effective approach for investigating the complex hydrological processes of groundwater over a range of spatial and temporal scales (Clark \& Frjtz, 1997; Gibson et al., 2005; Raghavendra et al., 2015; Wassenaar et al., 2011; Cui \& Li, 2014). The recharge area and recharge elevation of groundwater could be determined based on the elevation effect of isotope in precipitation and the Local Meteoric Water Line, due to the isotope composition of groundwater mainly depends on the recharge source (Clark \& Frjtz, 1997; Gu et al., 2011; Wang et al., 2015). Therefore, isotope and hydrochemical techniques are widely used to explore the recharge source and cyclic evolution of groundwater. For examples, Bicalho et al. (2019) developed a conceptual model for groundwater circulation by using isotopes and geochemical tracers. Younas et al. (2019) evaluated the recharge sources and geochemical identification in groundwater of the semi-arid alluvial aquifers of Pakistan based on stable isotopes and other major elemental data. Li et al. (2019) investigated the formation mechanism and mixing behaviour of Nanyang thermal spring based on isotopic and hydrochemistry techniques. 
Qinghai Lake, the largest saltwater lake in China with an area of $4264 \mathrm{~km}^{2}$, lies in the cold and semi-arid region of the north-eastern Tibetan Plateau. It is an important water body as well as an international wetland and China's national nature reserve for maintaining the ecological security of the north-eastern Tibetan Plateau (Tang et al., 1992; Cui \& Li, 2015a). Meanwhile, it is a key area for social and economic development in Qinghai Province, such as ecological tourism and animal husbandry. Furthermore, the Qinghai Lake Basin is a closed drainage basin, it has become an ideal area for studying global climate change, environmental evolution and the uplift process of the Qinghai Tibetan Plateau, as well as the water cycle and eco-hydrological processes, because of its sensitivity to global climate change. In recent decades, a series of ecological and environmental problems have already arisen under the influence of climate change and human activities, such as grassland degradation, wetland reduction, and biodiversity decline, which have attracted attention from the local governments as well as the international community ( Li et al., 2007; Xin, 2008; Cui et al., 2016). Previous studies, referring to geochemistry and water cycle of the Qinghai Lake Basin, were focus mainly on paleoclimate and environment change, lake evolution and its response to climate change, sources of precipitation, characteristics of river runoff, and so on (Chang et al., 2009; Cui \& Li., 2015a; Cui \& Li., 2015b; Fu et al., 2016; Tang et al., 2018). However, there are few studies having used the stable isotope and hydrochemical techniques to investigate the sources and water quality of the groundwater around Qinghai Lake.

Therefore, this study investigated water level, stable isotope and hydrochemistry of the groundwater around Qinghai Lake. The objectives are (1) to obtain the water level, stable isotope and hydrochemical characteristics of groundwater around Qinghai Lake; (2) to reveal and assess the water quality for drinking by analysing the ion concentrations (TDS, TH, $\mathrm{Na}^{+}, \mathrm{Cl}^{-}, \mathrm{SO}_{4}{ }^{2-}$, and $\mathrm{NO}_{3}{ }^{-}$); (3) to explore the possible causes of groundwater evolution and water quality. The results would contribute to knowledge about the hydrological and geochemical evolutions of groundwater around saltwater lakes in the Qinghai-Tibet Plateau, and inform water resource management in the Qinghai Lake Basin and Qinghai-Tibet Plateau.

\section{Study area}

The Qinghai Lake Basin (36 $\left.15^{\prime}-38 \mathrm{deg} 20^{\prime} \mathrm{N}, 97 \mathrm{deg} 50^{\prime}-101 \mathrm{deg} 20^{\prime} \mathrm{E}\right)$, a closed basin with an area of 29661 $\mathrm{km}^{2}$, lies in the cold and semiarid region of China's NE Qinghai-Tibet Plateau (Fig. 1). It also lies in a critical transitional zone where the Southeast Asian Monsoon (SEAM), the Westerly Circulation (WC) and the Qinghai-Tibet Plateau Monsoon meet (Cui \& Li., 2015a; Li et al., 2018). The area and water surface altitude of Qinghai Lake were $4425 \mathrm{~km}^{2}$ and $3195.82 \mathrm{~m}$ above sea level, respectively. The lake water has a salinity of $15.5 \mathrm{~g} / \mathrm{L}$ and a $\mathrm{pH}$ of 9.06 . Its water chemistry is characterised by ion proportions of $\mathrm{Na}^{+}>\mathrm{Mg}^{2+}>\mathrm{K}^{+}>\mathrm{Ca}^{2+}$ and $\mathrm{Cl}^{-}>\mathrm{SO}_{4}{ }^{2-}>\mathrm{CO}_{3}{ }^{2-}>\mathrm{NO}_{3}{ }^{-}$(Sun et al., 1991). Around the lake, the average annual air temperature is $-0.1 \mathrm{oC}$, and the average annual precipitation is $357 \mathrm{~mm}$ (Cui \& Li., 2015a). There are more than 50 rivers or streams flowing into Qinghai Lake (LZBCAS, 1994). The river system is unevenly distributed, being more developed in the west and north, and less in the east and south. River runoff is mainly sourced from the Buha, Shaliu, and Haergai Rivers, accounting for more than $75 \%$ of the total runoff into the lake.

The groundwater aquifers in the regions of late Palaeozoic marine limestone and sandstones, Silurian sandstone and schist, Triassic granite, and Quaternary deposits, are primarily carbonate aquifers, clastic rock aquifers, intrusive rock aquifers, and alluvial aquifers, respectively (Fig. 2; Cui \& Li., 2014). The buried depth of groundwater around Qinghai Lake usually varies between 4 and $7 \mathrm{~m}$. In the sparsely populated region, the buried depth is approximately 3 or $4 \mathrm{~m}$, which is shallower than the water table in the densely populated region (Xiao et al., 2012).

\section{Data source and methods}

The precipitation samples were collected from every precipitation event during the period from January to December in 2018 at the meteorological bureau of Gangcha (3301.5 m a.s.l.), Qinghai Province, China. During the sampling period, a total of 104 samples, including 83 of rainwater and 21 of snow or sleet, were collected, filtered and stored in $30 \mathrm{ml}$ high-density polyethylene square bottles for isotopic analyses. 
Groundwater samples were collected from 34 sites in September 2018, which were evenly distributed around Qinghai Lake (Fig. 1). Location information of sampling sites was acquired using a global positioning system (GPS). All samples were filtered through $0.45 \mu \mathrm{m}$ nylon filters. Water samples were stored in $30 \mathrm{ml}$ high-density polyethylene square bottles for isotopic analyses and two $100 \mathrm{ml}$ bottles for chemical analyses. Samples for cation testing were acidified with ultrapure $\mathrm{HCl}$. The samples for anion and isotope testing were transported with ice bags and refrigerated at approximately 4 until laboratory analysis. The $\mathrm{pH}$ and electrical conductivity (EC) of groundwater was measured in situ using a handheld meter with a probe. The stable isotopes were analysed using the Los Gatos Research IWA-45-EP Isotopic Water Analyzer. The isotopic values were reported using the standard $\delta$ notation relative to the V-SMOW (Venna Standard Mean Ocean Water) standard; the precisions were \pm 0.1 and $\pm 0.2 \delta^{18} \mathrm{O}$, respectively. The hydrochemical parameters of the groundwater samples were examined, including TDS (total dissolved solids), TH (total hardness), $\mathrm{Na}^{+}$, $\mathrm{K}^{+}, \mathrm{Mg}^{2+}, \mathrm{Ca}^{2+}, \mathrm{Cl}^{-}, \mathrm{SO}_{4}{ }^{2-}, \mathrm{CO}_{3}{ }^{2-}, \mathrm{HCO}_{3}{ }^{-}$, and $\mathrm{NO}_{3}{ }^{-}$. The cations of the samples were determined using a Dionex-600 ion chromatograph, and the anions were measured using a Dionex-500 ion chromatograph. $\mathrm{CO}_{3}{ }^{2-}$ and $\mathrm{HCO}_{3}{ }^{-}$were directly titrated in situ with phenolphthalein, methyl orange and sulfuric acid.

The Piper diagram (Piper, 1944) and the boomerang envelope model developed by Gibbs (Gibbs, 1970) were used to reveal the hydrochemical characteristics and evolution of groundwater. A Piper diagram generally used the major cations and anions of the water body to categorise the hydrogeochemical type of groundwater, river water and lake water, etc. (Piper, 1944; He et al., 2019). Gibbs (1970) analysed the chemical composition of surface water worldwide, and divided the factors controlling the composition of water into three endmembers, namely rock weathering, atmospheric precipitation, and evaporation/crystallisation (Machender et al., 2014). Meanwhile, the groundwater quality was assessed according to the Chinese State Standards for drinking water quality (Chinese Ministry of Health, 2006) and Chinese State Standards for groundwater water quality (Chinese General Administration of Quality Supervision, 2017). As shown in the standards, the highest acceptable limits of $\mathrm{pH}$, TH, TDS and the concentrations of $\mathrm{Na}^{+}, \mathrm{Cl}^{-}, \mathrm{NO}_{3}{ }^{-}$ and $\mathrm{SO}_{4}{ }^{2-}$ were $8.5,450 \mathrm{mg} / \mathrm{L}, 1000 \mathrm{mg} / \mathrm{L}, 200 \mathrm{mg} / \mathrm{L}, 250 \mathrm{mg} / \mathrm{L}, 20 \mathrm{mg} / \mathrm{L}$ and $250 \mathrm{mg} / \mathrm{L}$, respectively. In order to analyse the spatial characteristics of water level, isotope and hydrochemistry of groundwater around Qinghai Lake in more detail, the area around the lake was divided into four regions: east (G1-G11), south (G12-G20), west (G21-G29), and north (G30-G34) of Qinghai Lake.

\section{Results and discussion}

\subsection{Isotope characteristic of precipitation}

The $\delta^{18} \mathrm{O}$ values of precipitation ranged from -30.54 to $-0.76-222.63$ to -0.33 ranges reported previously for global $\left(-50-+10 \delta^{18} \mathrm{O},-350-+502001\right)$ and China $(-35.5-+2.5+24.0$ Water Line (LMWL) was simulated by using the $\delta^{18} \mathrm{O}$ and $\delta^{2} \mathrm{H}$ content of precipitation (Fig. 3): $\delta^{2} \mathrm{H}=7.80 \delta^{18} \mathrm{O}+10.98$ VSMOW $(\mathrm{n}=104$, $\mathrm{R}=0.985)$. The slope of LMWL was similar to the slopes of meteoric water lines for Lasa (7.90; Tian et al., 2001), northwestern China (7.05; Liu et al., 2008) and western China (7.56; Ma et al., 2009). All slopes were less than 8 , indicating that some non-equilibrium evaporation processes occurred as raindrops falling below the cloud base (Friedman et al., 1962; Dansgaard, 1964; Araguás-Araguás et al., 1998; Cui \& Li, 2015a; Zhang \&Wang, 2016). The LMWL was slightly above the GMWL due to the high d-excess value of precipitation in the Qinghai Lake Basin, suggesting that some continental moisture recycled to precipitation under low relative humidity conditions (Clark \& Fritz, 1997; Pang et al., 2011; Kong et al., 2013; Pang et al., 2017).

\subsection{Level variation of groundwater around Qinghai Lake}

Due to some residents' wells being sealed, groundwater level was investigated in only 14 sites among the 34 sampling sites around Qinghai Lake (Table 2). The buried depth of the groundwater level ranged from 0.85 to $10.87 \mathrm{~m}$ (mean $3.97 \mathrm{~m}$ ). The depth range was similar as that of previous study $(0.9 \mathrm{~m}-8.2 \mathrm{~m}$, mean $3.80 \mathrm{~m}$; Xiao et al., 2013). However, the buried depth of groundwater level couldn't reflect the direction of groundwater due to the different elevation among the sampling sites. The relative altitude between the groundwater level and the water level of Qinghai Lake was calculated at each sampling site (Table 2). The 
relative altitude of groundwater level ranged from -1.27 to $122.91 \mathrm{~m}$ (mean $25.70 \mathrm{~m}$ ). The relative altitudes of most of the groundwater level, excluding G6 and G29, were positive values (Table 2), indicating the groundwater level were higher than the water level of Qinghai Lake, and most of the groundwater flowed into the lake, while the groundwater in location G6 and G29 would be recharged by the lake water. Based on the data of the positive altitude of groundwater level (Table 2), the average relative altitude was calculated for each region around the lake and were arranged: south $>$ north $>$ west $>$ east, with altitude of $46.70 \mathrm{~m}$, $38.32 \mathrm{~m}, 38.04 \mathrm{~m}$, and $7.58 \mathrm{~m}$, respectively.

The hydraulic gradient of each groundwater was calculated based on the relative altitude of groundwater level and the distance between sample site and Qinghai Lake (Table 2). The hydraulic gradient ranged from -6.20 to 43.14gradient of each region around the lake was in the order: south $>$ east $>$ north $>$ west, with value of 19.70driving force of groundwater at the south of Qinghai Lake was stronger than other regions. According to the Fig. 2, fault escarpments and lacustrine sediment terraces had been developed extensively along the southern shore of Qinghai Lake, while the areas surrounding the lake and rivers were overlain by alluvial and lacustrine sediments whose age ranges from Quaternary to recent times(Fig. 2). The mountain runoff in the diluvial and alluvial plains recharged the groundwater via infiltration (Xiao et al. 2012). Therefore, the distribution and variation of groundwater level around Qinghai Lake would be mainly related to geomorphology, terrain, groundwater aquifers, fault, and so on (Jin et al., 2009; Xiao et al., 2012).

\subsection{Stable isotopes of groundwater around Qinghai Lake}

The $\delta^{18} \mathrm{O}$ values of the groundwater around Qinghai Lake ranged from -10.41 to $-5.86 \delta^{2} \mathrm{H}$ values ranged from -66.64 to -41.99 in the Qinghai Lake Basin (Fig. 3, Fig. 4). Comparing the groundwater samples with the local meteoric water line (LMWL) was useful for determining the water source in the investigation of the regional hydrology (Clark \& Fritz, 1997). Most of the isotope data points lay close to the LMWL, and the slope of local evaporation line of groundwater (LEL: $\delta^{2} \mathrm{H}=6.08 \delta^{18} \mathrm{O}-3.01$ ) was lower than the slope of LMWL (7.80; Fig. 4). These all indicated that the groundwater around Qinghai Lake mainly came from the precipitation in the basin, which had undergone variable degrees of evaporation before infiltration (Friedman et al., 1962; Gremillion \& Wanielista, 2000; Cui \& Li., 2014).

According to the Fig. 5, the $\delta^{18} \mathrm{O}$ values of the groundwater lying on the east, south, west and north of Qinghai Lake ranged from -10.41 to -7.78 and from -7.20 to $-6.68 \delta^{18} \mathrm{O}$ values of -8.62 respectively, indicating that the groundwater around the lake were recharged by precipitation at different altitude, and the precipitation had undergone variable degree of evaporation before infiltration (Friedman et al., 1962; Gremillion \& Wanielista, 2000; Cui \& Li., 2014). The average $\delta^{18} \mathrm{O}$ of the groundwater was in the order:

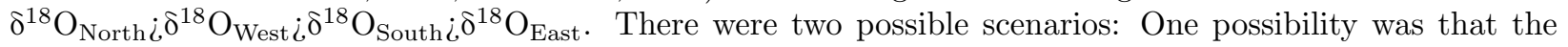
groundwater lying on the east of Qinghai Lake could have a relative higher recharge altitude than other regions around Qinghai Lake, the second possibility was that the groundwater lying on the north of Qinghai Lake could have undergone a stronger evaporation than other regions around the lake before infiltration. The LEL slope of groundwater lying on the east, south, west and north of Qinghai Lake was 7.25, 4.48, 4.22 and 3.94, respectively (Table 3; Fig. 4), indicating that evaporation degree of the groundwater before infiltration was in the order: North $>$ West $>$ South $>$ East (Weyhenmeyer et al., 2002; Dogramaci et al., 2012), the result was agreed upon that of the second possible scenario. Comparing with the east and south regions, the north and west regions overlain by alluvial and lacustrine sediments had a relatively flat terrain with low hydraulic gradient (Fig. 1, Fig. 2, Table 2), leading the surface water flowed slowly and had long time to infiltrate (Gibson et al. 2005; Buda, 2013). The longer time surface water infiltrated into groundwater, the higher evaporation degree the groundwater was undergone before infiltration (Weyhenmeyer et al., 2002). These all suggested that evaporation degree of the groundwater in west and north regions was higher than that in south and east of Qinghai Lake.

In order to eliminate the influence of evaporation on the groundwater, the intersection between the LEL of groundwater in each region and the LMWL of precipitation was calculated (Table 3). The values of $\delta^{2} \mathrm{H}$ and $\delta^{18} \mathrm{O}$ on the intersection were the recharge (initial) isotope values from precipitation to the groundwater (Clark \& Frjtz, 1997; Cui \& Li, 2014). The initial isotope value of the groundwater was in the order: 
$\delta_{\text {North }} \dot{\delta} \delta_{\text {West }} \dot{\delta} \delta_{\text {South }} \dot{\delta} \delta_{\text {East }}$, with value of -7.303). Due to altitude effect of $\delta^{18} \mathrm{O}$ in precipitation, the average recharge altitude of the groundwater in four regions was in the order: East $>$ South $>$ West $>$ North (Cui $\& \mathrm{Li}, 2014)$.

According to the Fig. 5, the $\delta^{18} \mathrm{O}$ value of G29 (-5.86of lake water (average $\delta^{18} \mathrm{O}: 1.61$ and the water level of G29 (relative altitude of $-1.27 \mathrm{~m}$, hydraulic gradient of -6.20 (Table 2), suggesting that the groundwater in location G29 would be recharged by Qinghai Lake water. The water level of G6 (relative altitude of $-0.12 \mathrm{~m}$ ) was also lower than the water level of Qinghai Lake (Table 2), but the $\delta^{18} \mathrm{O}$ value of G6 (-9.03relative low (Fig. 5). There could be two reasons for the low water level and low $\delta^{18} \mathrm{O}$ value in G6. One possibility was that the hydraulic connection between the G6 and lake water was not closely due to the slightly negative hydraulic gradient (-0.24second possibility was that the G6 was recharged by fissure water with relative depleted isotopes, because G6 was located on the fault zone of the southern margin of Zhongqilian Massif (Fig. 2). Overall, the groundwater around the lake was mainly recharged by precipitation, and the $\delta^{18} \mathrm{O}$ values of groundwater in different locations suggested that the altitude of the recharge areas varied.

\subsection{Hydrochemistry groundwater around Qinghai Lake}

The $\mathrm{pH}$ values of the groundwater around the lake ranged from 7.54 to 8.36 with a mean value of 8.04 , indicating that the groundwater was slightly alkaline. The $\mathrm{pH}$ values were similar as those of the river waters (7.60-8.55) in the Qinghai Lake Basin (Jin et al., 2010). The electrical conductivity (EC) and total dissolved solids (TDS) values of most of groundwater samples, excluding G4, G6 and G29, ranged from 0.39 to $1.76 \mathrm{mS} / \mathrm{cm}$ and from 269 to $885 \mathrm{mg} / \mathrm{L}$, respectively, with averages of $0.89 \mathrm{mS} / \mathrm{cm}$ and $523 \mathrm{mg} / \mathrm{L}$, respectively. Compared with the river water (the average EC and TDS were $0.17 \mathrm{mS} / \mathrm{cm}$ and $341.79 \mathrm{mg} / \mathrm{L}$, respectively) (Cui \& Li, 2015b), the EC and TDS of the groundwater were relatively high, indicating that the interaction between water and rocks was stronger in the groundwater than that in the river water. The hydrochemical type of most of groundwater samples, excluding G1, G4, G6, G7, G10, G11, G23, G25, and G29, was Ca-Mg- $\mathrm{HCO}_{3}$ (Fig. 6). The concentrations of $\mathrm{Ca}^{2+}$ and $\mathrm{Mg}^{2+}$ were relatively high, accounting for more than $60 \%$ of the cations. This finding indicated that the chemistry of groundwater would be mainly controlled by carbonate dissolution around Qinghai Lake.

For each index according to the Table 1, The TDS of groundwater at G4, G6 and G25 were more than 1000 $\mathrm{mg} / \mathrm{L}$; The $\mathrm{Na}^{+}$concentration of groundwater at G1, G4, G6, G25 and G29 were more than $170 \mathrm{mg} / \mathrm{L}$; The $\mathrm{Mg}^{2+}$ concentration of groundwater at $\mathrm{G} 4$ were more than $110 \mathrm{mg} / \mathrm{L}$; The $\mathrm{Cl}^{-}$concentration of groundwater at G4 and G6 were more than $140 \mathrm{mg} / \mathrm{L}$; The $\mathrm{SO}_{4}{ }^{2-}$ concentration of groundwater at G1, G4 and G25 were more than $150 \mathrm{mg} / \mathrm{L}$. And the hydrochemical types of G1, G4, G6, G25 and G29 were Na-Cl-SO 4 , Ca-Mg-Cl, $\mathrm{Na}-\mathrm{Cl}-\mathrm{CO}_{3}, \mathrm{Na}-\mathrm{Ca}-\mathrm{HCO}_{3}, \mathrm{Na}-\mathrm{Mg}-\mathrm{HCO}_{3}$, respectively (Fig. 6). There could be two reasons for the high TDS and high concentrations of $\mathrm{Na}^{+}, \mathrm{Mg}^{2+}, \mathrm{Cl}^{-}$, and $\mathrm{SO}_{4}{ }^{2-}$ in the groundwater. One possibility was that the longer flow path increased the interaction time between water and rocks and raised the dissolved solids; the second possibility was that the groundwater was recharged by the lake water. The relative altitude of water level of G29 (-1.27 m) was lower than water level of Qinghai Lake; the location of G29 is very near from Qinghai Lake, with the distance of $0.20 \mathrm{~km}$ (Table 1, Fig. 1); and the $\delta^{18} \mathrm{O}$ value of G29 (-5.86groundwater, indicating that there would have a significant hydraulic contact between G29 and the lake, and G29 would be recharged partly by the Qinghai Lake water (Cui et al., 2016). The $\delta^{18} \mathrm{O}$ of $\mathrm{G} 1\left(-8.29 \delta^{18} \mathrm{O}\right.$ of other groundwater around Qinghai Lake (Table 1), and G1 and G6 were located on the fault zone of the southern margin of Zhongqilian Massif (Fig. 2), indicating that the G1 and G6 were recharged partly by fissure water with relative depleted isotope. The relative altitudes of water level of G4 and G25 were higher than that of Qinghai Lake, and the $\delta^{18} \mathrm{O}$ value of G4 (-7.85G25 (-7.54significant hydraulic contact between G4, G25 and the lake. High TDS and high concentrations would be dominated by heavy evaporation or dissolved solids (Xiao et al., 2012; Cui \& Li, 2014). Meanwhile, G1, G4, G6, G25 and G29 were all located at east and west of Qinghai Lake (Fig. 1), suggesting that the sources of groundwater at east and west of Qinghai Lake were relative complex.

As shown in Fig. 7, all of the samples fell within the evolutionary path from "Rock dominance" to "Ocean" in the Gibbs boomerang envelope (Gibbs, 1970; Machender et al., 2014), suggesting that the chemical 
composition of the groundwater around the lake was dominated by rock-weathering. The results were supported by that rock weathering, ion exchange and precipitation were the major geochemical processes responsible for the solutes in the groundwater within the Qinghai Lake Basin (Xiao et al. 2012; Cui \& $\mathrm{Li}, 2014$ ). Meanwhile, relative high concentrations of $\mathrm{Na}^{+}$and $\mathrm{Cl}^{-}$in some groundwater were due to the evaporite dissolution in this area (Xu et al., 2010) or to the long migration path of groundwater with strong water-rock interaction (Cui \& Li, 2014).

\subsection{Evaluation of groundwater quality}

In drinking water, high concentrations of some ions could cause great harm to human health, such as $\mathrm{Na}^{+}$, $\mathrm{Cl}^{-}, \mathrm{NO}_{3}{ }^{-}, \mathrm{SO}_{4}{ }^{2-}$, and son on (Wasana et al., 2016; Nixdorf et al., 2017; Wasana et al., 2017). For example, high $\mathrm{NO}_{3}{ }^{-}$concentrations could result in birth defect, hypertension and high-Fe hemoglobin (Carpenter et al. 1998; Ho et al., 2011; Jones et al., 2016); high $\mathrm{SO}_{4}{ }^{2-}$ concentrations could cause diarrhea, dehydration and weight loss (World Health Organization, 2008). According to the Chinese State Standards for drinking water quality (Chinese Ministry of Health, 2006) and Chinese State Standards for groundwater water quality (Chinese General Administration of Quality Supervision, 2017), the highest acceptable limits of pH, TDS, total hardness $(\mathrm{TH})$ and the concentrations of $\mathrm{Na}^{+}, \mathrm{Cl}^{-}, \mathrm{SO}_{4}{ }^{2-}$, and $\mathrm{NO}_{3}{ }^{-}$were $8.5,1000 \mathrm{mg} / \mathrm{L}, 450 \mathrm{mg} / \mathrm{L}$, $200 \mathrm{mg} / \mathrm{L}, 250 \mathrm{mg} / \mathrm{L}, 250 \mathrm{mg} / \mathrm{L}$ and $20 \mathrm{mg} / \mathrm{L}$, respectively. As shown in Table 1 and Fig. 8, most of the groundwater was slightly and moderately hard freshwater, which fell within the standards for drinking water in all indices. However, the TDS of groundwater at location G4 $(1520.05 \mathrm{mg} / \mathrm{L}), \mathrm{G} 6(1092.44 \mathrm{mg} / \mathrm{L})$ and G25 (1497.42 mg/L) was higher than the highest acceptable limits set by the standard $(1000 \mathrm{mg} / \mathrm{L})$ (Table 1); the $\mathrm{Na}^{+}$concentration of groundwater at G6 $(371.34 \mathrm{mg} / \mathrm{L})$ and G25 $(308.21 \mathrm{mg} / \mathrm{L})$ were higher than the standard of $200 \mathrm{mg} / \mathrm{L}$; the $\mathrm{Cl}^{-}$concentration of groundwater at $\mathrm{G} 4(294.79 \mathrm{mg} / \mathrm{L})$ was higher than the standard of $250 \mathrm{mg} / \mathrm{L}$; and the $\mathrm{NO}_{3}{ }^{-}$concentration of groundwater at G4 $(100.88 \mathrm{mg} / \mathrm{L}), \mathrm{G} 11$ (53.82 mg/L), G16 $(74.46 \mathrm{mg} / \mathrm{L})$, G24 $(26.71 \mathrm{mg} / \mathrm{L})$ and G25 $(117.64 \mathrm{mg} / \mathrm{L})$ were higher than the standard of $20 \mathrm{mg} / \mathrm{L}$ (Fig. 8). These all indicated that the groundwater in location G4, G6, G11, G16, G24 and G25 were all currently exceed the drinking standards and not suitable for drinking (Carpenter et al. 1998; Ho et al., 2011; Wasana et al., 2016; Wasana et al., 2017). According to the results of water level, isotope and hydrochemistry of groundwater around Qinghai Lake, high TDS and concentrations of groundwater in location G4 and G25 were dominated by heavy evaporation or dissolved solids (Xiao et al. 2012; Cui \& Li, 2014). And high TDS and concentrations of groundwater in location G6 were dominated by recharging source of fissure water (Xu et al., 2010; Cui \& Li, 2014). These all reflected the influences of natural factors on groundwater quality, such as geomorphology, terrain, groundwater aquifers, fault, and so on (Jin et al., 2009; Xiao et al., 2012).

In generally, the concentration of nitrate nitrogen in the water was higher than $3.0 \mathrm{mg} / \mathrm{L}$, indicating that the water body was influenced by human activities (Babiker et al., 2004). As shown in Table 1, the concentration of $\mathrm{NO}_{3}{ }^{-}$in the groundwater were all higher than $4.60 \mathrm{mg} / \mathrm{L}$, indicating that the groundwater around Qinghai Lake was affected by human activities, especially in location G4, G11, G16, G24 and G25 with high $\mathrm{NO}_{3}{ }^{-}$ over the highest acceptable limits of $\mathrm{NO}_{3}{ }^{-}(20 \mathrm{mg} / \mathrm{L})$. Qinghai lake basin, lying in the Northeast QinghaiTibet Plateau, was a sparsely populated region with few mineral exploitation and large-scale factories (Li et al., 2018). Meanwhile, the region around the lake was a center of ecological tourism and animal husbandry for the Qinghai province (Tang et al., 1992). Therefore, the main sources of nitrate $\left(\mathrm{NO}_{3}{ }^{-}\right)$in groundwater around Qinghai Lake were animal feces and sewage. In order to further identify the source of nitrate in groundwater around the lake, the relationship between $\mathrm{NO}_{3}{ }^{-}$and $\mathrm{Cl}^{-}$of groundwater was analysed (Fig. 9). Because the ratio analysis of major ions in groundwater, such as $\mathrm{NO}_{3}^{-} / \mathrm{Cl}^{-}, \mathrm{SO}_{4}{ }^{2-} / \mathrm{Cl}^{-}$and $\mathrm{Cl}^{-} / \mathrm{Br}^{-}$, could be used to determine the source of nitrate pollution and the migration process of pollutants (Liu et al., 2006; Chen et al., 2009; Murgulet et al., 2013). As shown in the Fig. 9, there was a positive correlation between $\mathrm{NO}_{3}{ }^{-}$and $\mathrm{Cl}^{-}$ions in groundwater $(\mathrm{n}=34, \mathrm{P} ; 0.001, \mathrm{R}=0.747)$, further suggesting that the $\mathrm{NO}_{3}{ }^{-}$in groundwater was mainly originated from animal feces and sewage, which mainly came from the livestock breeding around Qinghai Lake.

Overall, the groundwater around Qinghai Lake came primarily from the atmospheric precipitation in the basin, the isotope and hydrochemistry of groundwater were mainly depended on the initial precipitation 
and the dissolution of surrounding rocks in runoff process, which were controlled by groundwater aquifers, fault, terrain and geomorphology (Jin et al., 2009; Xiao et al., 2012; Cui \& Li, 2014). But the impacts of livestock manure and waste water on groundwater quality could not be ignored around the lake, and even high concentrations of some ions in groundwater at east and west of Qinghai Lake had exceeded the highest acceptable limit values for drinking water. These suggested that the pollution of groundwater in animal husbandry areas on the Qinghai-Tibet Plateau should be paid more attention, although the industrial and urbanization rates were evenly relative low on the plateau (Wang et al, 2014). Hence, the scientific planning and engineering management of livestock manure and wastewater discharge in animal husbandry regions are very necessary to be carried out urgently, which could not only protect water resources for drinking, but also contribute to human health and sustainable development of the environment of the Qinghai-Tibet Plateau.

\section{Conclusions}

This study investigated the stable isotope of precipitation and water level, stable isotope and hydrochemistry of groundwater around Qinghai Lake. The LMWL was $\delta^{2} \mathrm{H}=7.80 \delta^{18} \mathrm{O}+10.98$, indicating that some nonequilibrium evaporation processes occurred as raindrops fell below the cloud base, and some continental moisture recycled to precipitation under low relative humidity conditions. Most of the groundwater points lay close to the LMWL, and the slope of LEL of groundwater was lower than the slope of LMWL, indicating that the groundwater around Qinghai Lake mainly came from the precipitation at different altitude in the basin, which had been undergone variable degrees of evaporation before infiltration. Most of the groundwater was slightly and moderately hard freshwater, and the hydrochemical type of groundwater was $\mathrm{Ca}-\mathrm{Mg}-\mathrm{HCO}_{3}$. The chemistry of groundwater would be mainly controlled by carbonate dissolution around Qinghai Lake. Meanwhile, the groundwater sources at east and west of Qinghai Lake were relative complex.

Most of the groundwater was slightly and moderately hard freshwater and fell within the standards for drinking water in all indices. However, the groundwater in location G4 (TDS, $\mathrm{Cl}^{-}$, and $\mathrm{NO}_{3}{ }^{-}$), G6 (TDS and $\left.\mathrm{Na}^{+}\right)$, G11 $\left(\mathrm{NO}_{3}{ }^{-}\right), \mathrm{G} 16\left(\mathrm{NO}_{3}{ }^{-}\right), \mathrm{G} 24\left(\mathrm{NO}_{3}{ }^{-}\right)$and G25 (TDS, $\mathrm{Na}^{+}$and $\left.\mathrm{NO}_{3}{ }^{-}\right)$were all currently exceed the drinking standards and not suitable for drinking. Overall, the impacts of livestock manure and waste water on groundwater quality could not be ignored around the lake. Scientific planning and engineering management of livestock manure and wastewater discharge in animal husbandry regions are very necessary to be carried out urgently, which could not only protect water resources for drinking, but also contribute to human health and sustainable development of the environment of the Qinghai-Tibet Plateau.

\section{Acknowledgements}

The study was supported by the National Natural Science Foundation of China (41730854, 41877157, 41530854); the Project supported by State Key Laboratory of Loess and Quaternary Geology (SKLLQG1904); the Science and technology support plan for Youth Innovation of colleges and universities of Shandong (2019KJH009); the Natural Science Foundation of Shandong Province (ZR2019BD005; ZR2019MD040); the Key Research and Development Plan of Shandong Province (2018GSF117021); the Science and technology program of colleges and universities of Shandong (J17KA192); and the Project supported by State Key Laboratory of Earth Surface Processes and Resource Ecology (2017-KF-15).

\section{Data Availability Statement}

Data available on request from the authors: The data that support the findings of this study are available from the corresponding author upon reasonable request.

\section{References}

Adams, S., Titus, R., Pietersen, K., Tredoux, G., Harris, C., 2001. Hydrochemical characteristics of aquifers near Sutherland in the Western Karoo, South Africa. Journal of Hydrology, 241(1-2): 91-103.

Araguas-Araguas, L., Froehlich, K., Rozanski, K., 1998. Stable isotope composition of precipitation over southeast Asia. Journal of Geophysical Research-Atmospheres, 103(D22): 28721-28742. 
Babiker, I.S., Mohamed, M.A.A., Teraoa, H., Kato, K., Ohta, K., 2004. Assessment of groundwater contamination by nitrate leaching from intensive vegetable cultivation using geographical information system. Environment International, 29 (8): 1009-1017.

Bicalho, C.C., Batiot-Guilhe, C., Taupin, J.D.,Patris, N., Van Exter, S., Jourde, H., 2019. A conceptual model for groundwater circulation using isotopes and geochemical tracers coupled with hydrodynamics: A case study of the Lez karst system, France. Chemical Geology, 528.

Buda, A.R., Kleinman, P.J.A., Feyereisen, G.W., Miller, D.A., Knight, P.G., Dorhan, P.J., Bryant, R.B., 2013. Forecasting runoff from Pennsylvania landscapes. Journal of Soil and Water Conservation, 68(3): 185-198.

Carpenter, S.R., Caraco, N.F., Correll, D.L., Howarth, R.W., Sharpley, A.N., Smith, V.H., 1998. Non-point pollution of surface waters with phosphorus and nitrogen. Ecological Applications, 8(3): 559-568.

Chang, H., Jin, Z.D., An, Z.S., 2009. Sedimentary evidences of the Uplift of the Qinghai Nanshan (the Mountains South to Qinghai Lake) and its implication for structural evolution of the Lake Qinghai Gonghe Basin. Geological Review, 55(1): 49-57. (in Chinese)

Chang, J., Wang, G.X., 2010. Major ions chemistry of groundwater in the arid region of Zhangye Basin, northwestern China. Environmental Earth Sciences, 61(3): 539-547.

Chen, F.J., Jia, G.D., Chen, J.Y., 2009. Nitrate sources and watershed denitrification inferred from nitrate dual isotopes in the Beijiang River, south China. Biogeochemistry, 94 (2):163-174.

Clark, I.D., Frjtz, P., 1997. Environmental isotopes in hydrogeology. New York: Lewis Publishers.

Cui, B.L., Li, X.Y., 2014. Characteristics of stable isotope and hydrochemistry of the groundwater around Qinghai Lake, NE Qinghai-Tibet Plateau, China. Environmental Earth Sciences, 71(3): 1159-1167.

Cui, B.L., Li, X.Y., 2015a. Stable isotopes reveal sources of precipitation in the Qinghai Lake Basin of the northeastern Tibetan Plateau. Science of the Total Environment, 527-528: 26-27.

Cui, B.L., Li, X.Y., 2015b. Characteristics of stable isotopes and hydrochemistry of river water in the Qinghai Lake Basin, northeast Qinghai-Tibet Plateau, China. Environmental Earth Science, 73(8): 4251-4263.

Cui, B.L., Li, X.Y., Wei, X.H., 2016. Isotope and hydrochemistry reveal evolutionary processes of lake water in Qinghai Lake. Journal of Great Lakes Research, 42(3): 580-587.

Dansgaard, W., 1964. Stable isotopes in precipitation. Tellus, 16(4): 436-468.

Dogramaci, S., Skrzypek, G., Dodson, W., Grierson, P.F., 2012. Stable isotope and hydrochemical evolution of groundwater in the semi-arid Hamersley Basin of subtropical northwest Australia. Journal of Hydrology, 475: 281-293.

Edmunds, W.M., 2009. Geochemistry's vital contribution to solving water resource problems. Applied Geochemistry, 24(6): 1058-1073.

Edmunds, W.M., Ma, J.Z., Aeschbach-Hertig, W., Kipfer, R., Darbyshire, D.P.F., 2006. Groundwater recharge history and hydrogeochemical evolution in the Minqin Basin, North West China. Applied Geochemistry, 21(12): 2148-2170.

Friedman, I., Machta, L., Soller, R., 1962. Water vapour exchange between a water droplet and its environment. Journal of Geophysical Research, 67(7): 2761-2766.

Fu, C.F., Bloemendal, J., Qiang, X.K., Hill, M.J., An, Z.S., 2016. Identification of greigite in the policene sediments of Qinghai Lake and its geological significance. Acta Geologica Sinica-English Edition, 90(6): 2261-2262.

Gibbs, R.J., 1970. Mechanisms controlling world water chemistry. Science, 170: 1088-1090. 
Gibson, J.J.., Edwards, T.W.D., Birks, S.J., St Amour, N,A,, Buhay, W.M., McEachern, P., Wolfe, B.B., Peters, D.L., 2005. Progress in isotope tracer hydrology in Canada. Hydrological Processes, 19(1): 303-327.

Giordano, M., 2009. Global groundwater? Issues and solutions. Annual Review of Environment and Resources, 34: 153-178.

Gleeson, T., Befus, K.M., Jasechko, S., 2016. The global volume and distribution of modern groundwater. Nature Geoscience, 9(2): 161-167.

Gleeson, T., Wada, Y., Bierkens, M.F.P., van Beek, L.P.H., 2012. Water balance of global aquifers revealed by groundwater footprint. Nature, 488: 197-200.

Goldin, T., 2016. Groundwater: India's drought below ground. Nature Geoscience, 9(2): 98.

Gremillion, P., Wanielista, M., 2000. Effects of evaporative enrichment on the stable isotope hydrology of a central Florida (USA) river. Hydrological Processes, 14(8): 1465-1484.

Gu, W.Z., Pang, Z.H., Wang, Q.J., Song, X.F., 2011. Isotope Hydrology. Science Press, Beijing. (in Chinese)

He, S., Wu, J.H., 2019. Hydrogeochemical Characteristics, Groundwater Quality, and Health Risks from Hexavalent Chromium and Nitrate in Groundwater of Huanhe Formation in Wuqi County, Northwest China. Exposure and Health, 11(2): 125-137.

Ho, C.K., Yang, Y.H., Yang, C.Y., 2011. Nitrates in drinking water and the risk of death from brain cancer: Does hardness in drinking water matter? Journal of Toxicology and Environmental Health-Part A-Current Issues, 74(12): 747-756.

IAEA/WMO., 2001. Global network for isotopes in precipitation [EB/OL].

Jin, Z.D., Wang, S.M., Zhang, F., Shi, Y.W., 2010. Weathering, Sr fluxes, and controls on water chemistry in the Lake Qinghai catchment, NE Tibetan Plateau. Earth Surface Processes and Landforms, 35(9): 10571070 .

Jin, Z.D., Yu, J.M., Wang, S.M., Zhang, F., Shi, Y.W., You, C.F., 2009. Constraints on water chemistry by chemical weathering in the Lake Qinghai catchment, northeastern Tibetan Plateau (China): clues from Sr and its isptppic geochemistry. Hydrogeology Journal, 17(8): 2037-2048.

Jones, R.R., Weyer, P.J., Dellavalle, C.T., Inoue-Choi, M., Anderson, K., Cantor, K.P., Krasner, S., Robien, K., Freeman, L.E.B., Silverman, D., Ward, M.H., 2016. Nitrate from drinking water and diet and bladder cancer among postmenopausal women in Iowa. Environmental Health Perspectives, 124(11): 1751-1758.

Kong, Y.L., Pang, Z.H., Froehlich, K. 2013. Quantifying recycled moisture fraction in precipitation of an arid region using deuterium excess. Tellus Series B-Chemical and Physical Meteorology, 65B: 19251.

Li, N., Zhou, H., Wen, Z., Jakada, H., 2019. Formation mechanism and mixing behaviour of Nanyang thermal spring, Xingshan County of Hubei Province, central China. Hydrogeology Journal, 27(8): 2933-2953.

Li, P.Y., Qian, H., Wu, J.H., Zhang, Y.Q., Zhang, H.B., 2013. Major ion chemistry of shallow groundwater in the Dongsheng coalfield, Ordos Basin, China. Mine Water and the Environment, 32(3): 195-206.

Li, X.Y., Ma, Y.J., Huang, Y.M., 2018. Study on eco-hydrological process and water balance in Qinghai Lake Basin. Science Press, Beijing. (in Chinese)

Li, X.Y., Xu, H.Y., Sun, Y.L., Zhang, D.S., Yang, Z.P., 2007. Lake-level change and water balance analysis at Lake Qinghai, west China during recent decades. Water Resources Management, 21(9): 1505-1516.

Liu, C.Q., Li, S.L., Lang, Y.C., Xiao, H.Y., 2006. Using $\delta^{15} \mathrm{~N}$ - and $\delta^{18} \mathrm{O}$-values to identify nitrate sources in karst ground water, Guiyang, Southwest China. Environmental Science and Technology, 40(22): 6928-6933. 
Liu, F., Song, X.F., Yang, L.H., Han, D.M., Zhang, Y.H., Ma, Y., Bu, H.M., 2015. The role of anthropogenic and natural factors in shaping the geochemical evolution of groundwater in the Subei Lake basin, Ordos energy base, Northwestern China. Science of the Total Environment, 538: 327-340.

Liu, J.R., Song, X.F., Yuan, G.F., Sun, X.M., Liu, X., Chen, F., Wang, Z.M., Wang, S.Q., 2008. Characteristics of $\delta^{18} \mathrm{O}$ in precipitation over Northwest China and its water vapor sources. Acta Geographica Sinica, 63(1): 12-22. (in Chinese)

LZBCAS (Lanzhou Branch of Chinese Academy of Sciences), 1994. Evolution of recent environment in Qinghai Lake and its prediction. Science Press, Beijing. (in Chinese)

Ma, J., Ding, Z., Edmunds, W.M., Gates, J.B., Huang, T.M., 2009. Limits to recharge of groundwater from Tibetan plateau to the Gobi desert, implications for water management in the mountain front. Journal of Hydrology, 364(1-2): 128-141.

Machender, G., Dhakate, R., Reddy, M.N., Reddy, I.P., 2014. Hydrogeochemical characteristics of surface water(SW) and groundwater(GW) of the Chinnaeru River basin, northern part of Nalgonda District, Andhra Pradesh, India. Environmental Earth Sciences, 71(6): 2885-2910.

Matter, J., Waber, H.N., Loew, S., Matter, A2006. Recharge areas and geochemical evolution of groundwater in an alluvial aquifer system in the Sultanate of Oman. Hydrogeology Journal, 14(1-2): 203-224.

Murgulet, D. Tick, G.R., 2013. Understanding the sources and fate of nitrate in a highly developed aquifer system. Journal of Contaminant Hydrology, 155: 69-81.

Nixdorf, E., Sun, Y.Y., Lin, M., Kolditz, O., 2017. Development and application of a novel method for regional assessment of groundwater contamination risk in the Songhua River Basin. Science of the Total Environment, 605: 598-609.

Oki, T., Kanae, S., 2006. Global hydrological cycles and world water resources. Science, 313(5790): 10681072 .

Pang, Z.H., Kong, Y.L., Froehlich, K., Huang, T.M., Yuan, L.J., Li, Z.Q., Wang, F.T. 2011. Processes affecting isotopes in precipitation of an arid region. Tellus Series B-Chemical and Physical Meteorology, 63(3): 352-359.

Pang, Z.H., Kong, Y.L., Li, J., Tian, J., 2017. An isotopic geoindicator in the hydrological cycle, Procedia Earth and Planetary Science, 17: 534-537.

Piper, A.M., 1944. A graphic procedure in the geochemical interpretation of water-analysis. Trans Am Geophys Union, 25(6): 914-923.

Postel, S.L., Daily, G.C., Ehrlich, P.R., 1996. Human appropriation of renewable fresh water. Science, 271(5250): 785-788. Qiu, J., 2010. China faces up to groundwater crisis. Nature, 466: 308.

Raghavendra, N.S., Deka, P.C., 2015. Sustainable development and management of groundwater resources in Mining Affected Areas: A Review. Procedia Earth and Planetary Science, 11: 598-604.

Rodell, M., Velicogna, I., Famiglietti, J.S., 2009. Satellite-based estimates of groundwater deletion in India. Nature, 460(7258): 999-1002.

Siebert, S., Burke, J., Faures, J.M., Frenken, K., Hoogeveen, J., Doll, P., Portmann, F.T., 2010.Groundwater use for irrigation-a global inventory. Hydrology and Earth System Sciences, 14(10): 1863-1880.

Sun, D.P., Tang, Y., Xu, Z.Q., Han, Z.M., 1991. A preliminary investigation on chemical evolution of the Lake Qinghai water, China. Chinese Science Bulletin, 37(3): 221-225.

Tang, L.Y., Duan, X.F., Kong, F.J., Zhang, F., Zheng, Y.F., Li, Z., Mei, Y., Zhao, Y.W., Hu, S.J., 2018. Influences of climate change on area variation of Qinghai Lake on Qinghai-Tibetan Plateau since 1980s. Scientific Reports, 8: 7331. 
Tang, R.C., Gao, X.Q., Zhang, J., 1992. The annual changes of the water level of the Lake Qinghai in the recent thirty years. Chinese Science Bulletin, 37(6): 524. (in Chinese)

Tian, L.D., Yao, T.D., Sun, W.Z., Stievenard, M., Jouzel, J., 2001. Relationship between $\delta \mathrm{D}$ and $\delta^{18} \mathrm{O}$ in precipitation from north to south of the Tibetan Plateau and moisture cycling. Science in China, 44(9): 789-796. (in Chinese)

Van Loon, A.F., Gleeson, T., Clark, J., Van Dijk, A.I.J.M., Stahl, K., Hannaford, J., Di Baldassarre, G., Teuling, A.J., Taallaksen, L.M., Uijlenhoet, R., Hannah, D.M., Sheffield, J., Svoboda, M., Verbeuren, B., Wangener, T., Rangecroft, S., Wanders, N., Van Lanen, H.A.J., 2016. Drought in the Anthropocene. Nature Geoscience, 9(2): 89-91.

Vorosmarty, C. J., Green, P., Salisbury, J., Lammers, R.B., 2000. Global water resources: vulnerability from climate change and population growth. Science, 289(5477): 284-288.

Wada, Y., Van Beek, L.P.H., Bierkens, M.F.P., 2012. Nonsustainable groundwater sustaining irrigation: a global assessment. Water Resources Research, 48: W00L06.

Wang, J.S., Chen, J.S., Lu, B.H., Tong, H.B., Tan, Z.C., Sun, Y.Y., Lin, T., Wang, Y.S., 2015. Review and prospect of isotope hydrology. Journal of Hohai University (Natural Science), 43(5): 406-413. (in Chinese)

Wang, X.M., Chai, Y.W., Cheng, C., Bu, Y.J., 2014. Impact assessment of ecological service value in the rapid urbanization area of Qinghai-Tibet Plateau: a case study of Xining. China Population, Resources and Environment, 24(5): 435-439.

Wasana, H.M.S., Aluthpatabendi, D., Kularatne, W.M.T.D., Wijekoon, P., Weerasooriya, R., Bandara, J., 2016. Drinking water quality and chronic kidney disease of unknown etiology (CKDu): synergic effects of fluoride, cadmium and hardness of water. Environmental Geochemistry and Health, 38(1): 157-168.

Wasana, H.M.S., Perera, G.D.R.K., Gunawardena, P.D., Fernando, P.S., Bandara, J., 2017. WHO water quality standards vs Synergic effect(s) of fluoride, heavy metals and hardness in drinking water on kidney tissues. Scientific Reports, 7: 42516.

Wassenaar, L.I., Athanasopoulous, P., Hendry, M.J., 2011. Isotope hydrology of precipitation, surface and ground waters in the Okanagan Valley, British Columbia, Canada. Journal of Hydrology, 411(1-2): 37-48.

Weyhenmeyer, C.E., Burns, S.J., Waber, H.N., Macumber, P.G., 2002. Isotope study of moisture sources, recharge areas, and groundwater flow paths within the eastern Batinah coastal plain, Sultanate of Oman. Water Resources Research, 38(10): 1184-1206.

Xiao, J., Jin, Z.D., Zhang, F., 2013. Geochemical and isotopic characteristics of shallow groundwater within the Lake Qinghai catchment, NE Tibetan Plateau. Quaternary International, 313-314: 62-73.

Xiao, J., Jin, Z.D., Zhang, F., Wang, J., 2012. Solute geochemistry and its sources of the groundwater's in the Qinghai Lake Catchment, NW China. Journal of Asian Earth Science, 52: 21-30.

Xin, H., 2008. A green fervor sweeps the Qinghai-Tibetan Plateau. Science, 321(5889): 633-635.

Xu, H., Hou, Z., An, Z., Liu, X., Dong, J., 2010. Major ion chemistry of waters in Lake Qinghai catchments, NE Qinghai-Tibet plateau, China. Quaternary International, 212(1): 35-43.

Younas, A., Mushtaq, N., Khattak, J.A., Javed, T., Rehman, H.U., Farooqi, A., 2019. High levels of fluoride contamination in groundwater of the semi-arid alluvial aquifers, Pakistan: evaluating the recharge sources and geochemical identification via stable isotopes and other major elemental data. Environmental Science and Pollution Research, 26(35): 35728-35741.

Zhang, M.J., Wang, S.J., 2016. A review of precipitation isotope studies in China: basic pattern and hydrological process. Journal of Geographical Science, 26(7): 921-938.

\section{Captions of Figures and Tables}


Fig. 1. Location of the Qinghai Lake Basin and sites for sampling precipitation and groundwater

Fig.2. Geological map and elevation contours of the Qinghai Lake Basin

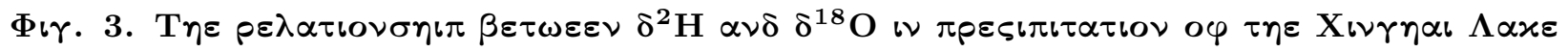
B $\alpha \sigma$ or Irupe

Fig. 4. Characteristics of the stable isotope of groundwater in four regions with the LMWL in the Qinghai Lake Basin

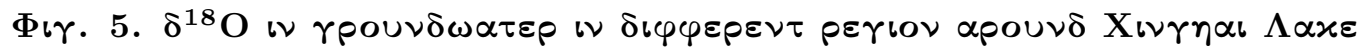

Fig. 6. Ternary plots of cations and anions of the groundwater around Qinghai Lake

Fig. 7. Plots of the major ions within the Gibbs boomerang model for groundwater around Qinghai Lake

Fig.8. Concentrations of $\mathrm{Na}^{+}, \mathrm{Cl}^{-}, \mathrm{SO}_{4}{ }^{2-}$, and $\mathrm{NO}_{3}{ }^{-}$in groundwater around Qinghai Lake

Fig. 9. Relationship between $\mathrm{NO}_{3}{ }^{-}$and $\mathrm{Cl}^{-}$in groundwater around Qinghai Lake

Table 1. Stable isotope and hydrochemical compositions of the groundwater around Qinghai Lake

Table 2. The water level information of 14 groundwater around Qinghai Lake

Table 3. The evaporation line of groundwater in different parts around Qinghai Lake

Hosted file

Tables.docx available at https://authorea.com/users/304263/articles/434645-stable-isotopeand-hydrochemistry-reveal-source-and-quality-of-groundwater-around-qinghai-lake-neqinghai-tibet-plateau-china

Hosted file

Figures.docx available at https://authorea.com/users/304263/articles/434645-stable-isotopeand-hydrochemistry-reveal-source-and-quality-of-groundwater-around-qinghai-lake-ne-

qinghai-tibet-plateau-china 